Article

\title{
The Important Role of Dissolved Oxygen Supply Regulated by the Hydraulic Shear Force during the Biosynthesis of Iron Hydroxysulfate Minerals
}

\author{
Jun Yang, Rui Wang, Heru Wang and Yongwei Song *(D) \\ Department of Environmental Engineering, School of Information and Safety Engineering, \\ Zhongnan University of Economics and Law, Wuhan 430073, China; z0004221@zuel.edu.cn (J.Y.); \\ wr980317@163.com (R.W.); z0004382@zuel.edu.cn (H.W.) \\ * Correspondence: songyongwei@zuel.edu.cn; Tel.: +86-027-8838-5169
}

Received: 7 April 2020; Accepted: 1 June 2020; Published: 5 June 2020

check for updates

\begin{abstract}
The severity of environmental pollution from acid mine drainage (AMD) is increasingly garnering attention. In this study, the effects of hydraulic shear forces (achieved by regulating the shaking table's rotation speed) on $\mathrm{Fe}^{2+}$ bio-oxidation and $\mathrm{Fe}^{3+}$ hydrolytic mineralization in an acidic 9K medium- $\mathrm{FeSO}_{4}$-Acidithiobacillus ferrooxidans system (simulated AMD) are investigated. Results reveal that a higher shaking speed favors a higher oxidation rate of $\mathrm{Fe}^{2+}$, whereas a very low or high shaking speed restricts the removal of $\mathrm{Fe}^{3+}$. Shaking table rotation speeds of 120-180 rpm were preferred for biomineralization treatment in the simulated AMD. As the initial concentration of $\mathrm{Fe}^{2+}$ in the system decreased from 9.67 to $0 \mathrm{~g} / \mathrm{L}$ in $40 \mathrm{~h}$, the dissolved $\mathrm{O}_{2}$ (DO) in the solution dropped to its lowest concentration after $20 \mathrm{~h}$ and then increased to its initial level between 40 and $120 \mathrm{~h}$. However, the corresponding total $\mathrm{Fe}(\mathrm{TFe})$ precipitation efficiency increased with the increasing mineralization time after $40 \mathrm{~h}$. The effect of $\mathrm{O}_{2}$ supply time on biomineralization revealed that $\mathrm{DO}$ was mainly used in $\mathrm{Fe}^{2+}$ bio-oxidation. After $\mathrm{Fe}^{2+}$ was completely oxidized by A. ferrooxidans, the precipitation efficiency of TFe was independent of the $\mathrm{O}_{2}$ supply.
\end{abstract}

Keywords: acid mine drainage; Acidithiobacillus ferrooxidans; hydraulic shear force; dissolved oxygen; biomineralization; iron hydroxysulfate minerals

\section{Introduction}

When exposed to air and water, sulfidic wastes undergo atmospheric and aqueous oxidation and tend to generate acid mine drainage (AMD), which often contains elevated concentrations of soluble $\mathrm{Fe}\left(\mathrm{Fe}^{2+}\right.$ and $\left.\mathrm{Fe}^{3+}\right), \mathrm{SO}_{4}{ }^{2-}$ and heavy metals [1,2]. The oxidation of pyrite to sulfate in AMD systems is described by the following two end-member reactions that utilize either $\mathrm{O}_{2}$ or $\mathrm{Fe}^{3+}$ as oxidants [3].

$$
\begin{gathered}
\mathrm{FeS}_{2}+7 / 2 \mathrm{O}_{2}+\mathrm{H}_{2} \mathrm{O} \rightarrow \mathrm{Fe}^{2+}+2 \mathrm{SO}_{4}{ }^{2-}+2 \mathrm{H}^{+} \\
\mathrm{FeS}_{2}+14 \mathrm{Fe}^{3+}+8 \mathrm{H}_{2} \mathrm{O} \rightarrow 15 \mathrm{Fe}^{2+}+2 \mathrm{SO}_{4}{ }^{2-}+16 \mathrm{H}^{+}
\end{gathered}
$$

AMD corrodes the underground pipes, drainage pumps and other related equipment and cause acid and heavy metal pollution of vast water resources and soils, considerably affecting the daily productivity and life. Therefore, AMD is a global environmental problem even though several predictive and preventive techniques have been developed.

Currently, neutralization is the most mature and widely used method for handling AMD [4-6]; however, this method has many limitations. For example, some soluble $\mathrm{Fe}$ in AMD remains as $\mathrm{Fe}^{2+}$ and the $\mathrm{pH}(>8.5)$ required for the complete precipitation of $\mathrm{Fe}^{2+}$ in the hydroxide form is significantly 
higher than that required for the complete precipitation of $\mathrm{Fe}^{3+}(\mathrm{pH}=3.5)$, considerably decreasing the demand for the neutralization reagent. When AMD passes through a limestone ditch, $\mathrm{Fe}^{2+}, \mathrm{Fe}^{3+}$ and $\mathrm{SO}_{4}{ }^{2-}$ easily produce high amounts of flocculent sediments comprising $\mathrm{Fe}(\mathrm{OH})_{2}, \mathrm{Fe}(\mathrm{OH})_{3}$ and $\mathrm{CaSO}_{4}$. These compounds adhere to the limestone particle surfaces, acting as barriers and preventing further reaction between the reagent and water. Thus, the filter medium is blocked in the dewatering stage, inducing poor dehydration performance and reduced treatment efficiency [7-9]. Obviously, quickly transforming $\mathrm{Fe}^{2+}$ to $\mathrm{Fe}^{3+}$ and controlling the formation of $\mathrm{Fe}(\mathrm{OH})_{3}$ and $\mathrm{CaSO}_{4}$ are critical issues that must be resolved to optimize the lime neutralization technology in case of AMD.

However, for a solution having $\mathrm{pH}<3.5$, the air oxidation rate constant of $\mathrm{Fe}^{2+}$ is only $10^{-3.5} / \mathrm{d}[10]$. Bosecker [11] indicates that $A$. ferrooxidans increases the oxidation rate of $\mathrm{Fe}^{2+}$ by approximately $10^{5}-10^{6}$ in an acid sulfate environment. Furthermore, this oxidation is frequently accompanied by the hydrolysis and mineralization of the produced $\mathrm{Fe}^{3+}$ to form iron hydroxysulfate minerals such as schwertmannite and jarosite [12,13]. Equations (3)-(5) represent the schwertmannite and jarosite formation processes [14].

$$
\begin{gathered}
4 \mathrm{Fe}^{2+}+\mathrm{O}_{2}+4 \mathrm{H}^{+} \rightarrow 4 \mathrm{Fe}^{3+}+2 \mathrm{H}_{2} \mathrm{O} \\
8 \mathrm{Fe}^{3+}+14 \mathrm{H}_{2} \mathrm{O}+\mathrm{SO}_{4}{ }^{2-} \rightarrow \mathrm{Fe}_{8} \mathrm{O}_{8}(\mathrm{OH})_{6} \mathrm{SO}_{4} \text { (schwertmannite) }+22 \mathrm{H}^{+} \\
\mathrm{M}^{+}+3 \mathrm{Fe}^{3+}+2 \mathrm{SO}_{4}{ }^{2-}+6 \mathrm{H}_{2} \mathrm{O} \rightarrow \mathrm{MFe}_{3}\left(\mathrm{SO}_{4}\right)_{2}(\mathrm{OH})_{6} \text { (jarosite) }+6 \mathrm{H}^{+}
\end{gathered}
$$

$\mathrm{M}^{+}$represents $\mathrm{K}^{+}, \mathrm{NH}_{4}{ }^{+}, \mathrm{Na}^{+}$and $\mathrm{H}_{3} \mathrm{O}^{+}$. In addition, the iron hydroxysulfate minerals can be directly synthesized via chemical methods. For example, under acidic conditions, schwertmannite can be obtained via iron salt hydrolysis or ferrous salt oxidation $\left(\mathrm{FeSO}_{4}-\mathrm{H}_{2} \mathrm{O}_{2}\right)$ [15-17]. Iron hydroxysulfate minerals are ideal materials for the adsorption and coprecipitation of heavy metals in AMD [18-20]. Therefore, the A. ferrooxidans-mediated biomineralization is an efficient AMD treatment method, exhibiting significant economic and environmental benefits.

The primary factors controlling the formation of iron hydroxysulfate minerals are the reaction time, temperature, acidity, $\mathrm{Fe}^{2+}$ concentration and the monovalent cation type and concentration $\left(\mathrm{K}^{+}, \mathrm{Na}^{+}\right.$, $\mathrm{NH}_{4}{ }^{+}$, etc.) [21-24]. In an extremely acidic environment, the $A$. ferrooxidans-mediated biomineralization involves the biologic oxidation of $\mathrm{Fe}^{2+}$ and thus facilitate $\mathrm{Fe}$ hydrolysis. Previous studies showed that schwertmannite formation usually occurs in Fe and sulfate-rich solutions in a $\mathrm{pH}$ range of 2.5-4.5, with lower $\mathrm{pH}$ values promoting the precipitation of jarosite. For instance, Bigham et al. [25] demonstrated that schwertmannite, formed through the bio-oxidation of $\mathrm{Fe}^{2+}$ by A.ferrooxidans, was the only mineral phase at $\mathrm{pH}=3.0$. Liao et al. [26] observed that the formed ferric hydroxysulfate minerals were a mixture of $\mathrm{Na}$-jarosite and schwertmannite at an initial $\mathrm{pH}$ of 3.5; however, a $\mathrm{pH}$ of 1.6-3.4 produced only pure schwertmannite. As an aerobic autotrophic bacterium, A. ferrooxidans utilizes $\mathrm{Fe}^{2+}$ as the electron donor and $\mathrm{O}_{2}$ as the electron acceptor for oxidization to $\mathrm{Fe}^{3+}$. It also uses $\mathrm{CO}_{2}$ as the carbon source and $\mathrm{N}$ and $\mathrm{P}$ as the nutrient elements. Further, it employs the energy obtained via the oxidation of $\mathrm{Fe}^{2+}$ to support its growth and reproduction $[27,28]$. Many studies have investigated the effects of $\mathrm{O}_{2}$ supply on $\mathrm{Fe}^{2+}$ oxidation, growth and metabolism of $A$. ferrooxidans. For example, Ohmura et al. [29] indicated that the growth of $A$. ferrooxidans is inhibited at a dissolved $\mathrm{O}_{2}$ (DO) concentration of less than $0.29 \mathrm{mg} / \mathrm{L}$ and terminated at $0.2 \mathrm{mg} / \mathrm{L}$. Goodman et al. [30] reported that bacteria can survive under anaerobic conditions when the oxidation potential of $A$. ferrooxidans for pyrite $\left(\mathrm{FeS}_{2}\right)$ decreases rapidly at DO levels of lower than $3 \mu \mathrm{mol} / \mathrm{L}$. Magdalene et al. [31] reported positive correlations between the concentration of $\mathrm{DO}$ and the oxidation rate of $\mathrm{FeS}_{2}$ as well as the cell synthesis of $A$. ferrooxidans. $\mathrm{O}_{2}$ is vital with respect to the oxidation ability, growth and reproduction of $A$. ferrooxidans. In acidic sulfate environments, such as $\mathrm{AMD}$, the $\mathrm{Fe}^{2+}$ bio-oxidation and $\mathrm{Fe}^{3+}$ hydrolysis reactions are coupling reactions of the $A$. ferrooxidans-mediated biomineralization. However, the effect of the DO supply level on the $\mathrm{Fe}^{3+}$ hydrolysis reactions in the system has been rarely investigated. Liao et al. [26] observed that a significant amount of yellowish hydroxysulfate precipitates was generated by statically incubating the $\mathrm{FeSO}_{4}$ solution containing $A$. ferrooxidans for 
$40 \mathrm{~h}$, implying that DO may not be indispensable throughout the experiment for the biosynthesis of the iron hydroxysulfate minerals. However, this assumption is not supported by direct evidence.

The objective of this study was to investigate the influence of DO on the formation of iron hydroxysulfate minerals by A. ferrooxidans. Proper hydraulic shear force can maintain the uniformity of a three-phase system (gas-liquid-solid), ensuring a high concentration of DO in the solution and maintaining good heat transfer in the system [32,33]. The effects of the hydraulic shear force on the $\mathrm{Fe}^{2+}$ oxidation, total Fe (TFe) precipitation, DO concentration, iron hydroxysulfate mineral yield or phase were investigated by adjusting the rotating speed of the shaking table. These investigations provide the necessary theoretical basis for promoting the regulation and biologic transformation of Fe in AMD to iron hydroxysulfate minerals.

\section{Materials and Methods}

\subsection{Preparation of the Modified 9K Liquid Medium}

The modified 9K liquid medium was prepared as follows: $3.5 \mathrm{~g}$ of $\left(\mathrm{NH}_{4}\right)_{2} \mathrm{SO}_{4}, 0.119$ of $\mathrm{KCl}$, 0.058 of $\mathrm{K}_{2} \mathrm{HPO}_{4}, 0.0168$ of $\mathrm{Ca}\left(\mathrm{NO}_{3}\right)_{2} \cdot 4 \mathrm{H}_{2} \mathrm{O}$ and $0.583 \mathrm{~g}$ of $\mathrm{MgSO}_{4} \cdot 7 \mathrm{H}_{2} \mathrm{O}$ in $1 \mathrm{~L}$ of distilled water, adjusted to $\mathrm{pH}=2.50$ with $1: 1(v / v) \mathrm{H}_{2} \mathrm{SO}_{4}$, followed by sterilization using a sterilizer for $30 \mathrm{~min}$ at $121{ }^{\circ} \mathrm{C}[34]$.

\subsection{Preparation of the A. ferrooxidans Resting Cells}

A. ferrooxidans (CGMCC0727) was obtained from the China General Microbial Culture Collection Center (Beijing, China). Sterilized $\mathrm{FeSO}_{4} \cdot 7 \mathrm{H}_{2} \mathrm{O}$ was added to an Erlenmeyer flask containing $225 \mathrm{~mL}$ of the modified 9K liquid medium, which was inoculated with $25 \mathrm{~mL}$ of $A$. ferrooxidans to obtain an $\mathrm{Fe}^{2+}$ concentration of $9.67 \mathrm{~g} / \mathrm{L}$. After evenly mixing the solution, the flask was shaken and cultured in a shaker at $28{ }^{\circ} \mathrm{C}$ and $180 \mathrm{rpm}$, and the culture was terminated later in the exponential growth stage (approximately $3 \mathrm{~d}$ ). The culture medium was filtered using 1004-055 Whatman filter paper (Grade 4: 20-25 $\mu \mathrm{m}$ ) to collect the iron hydroxysulfate minerals, whereas the filtrate was centrifuged at $7720 \mathrm{rpm}$ to collect the concentrated bacteria and then washed twice using dilute $\mathrm{H}_{2} \mathrm{SO}_{4}(\mathrm{pH}=1.50)$ to eliminate the various doped ions. Finally, the centrifuged cells were resuspended in dilute $\mathrm{H}_{2} \mathrm{SO}_{4}$ at an optimum $\mathrm{pH}$ of 2.50, producing the $A$. ferrooxidans resting cells [26]. The density of $A$. ferrooxidans was approximately $5 \times 10^{8}$ cells $/ \mathrm{mL}$.

\subsection{Effect of Hydraulic Shear Force on $\mathrm{Fe}^{2+}$ Bio-Oxidation and $\mathrm{Fe}^{3+}$ Hydrolysis by A. ferrooxidans}

In a series of 500-mL Erlenmeyer flasks, $225 \mathrm{~mL}$ of the modified 9K liquid medium and $25 \mathrm{~mL}$ of the $A$. ferrooxidans resting cells were added to produce an inoculation with $10 \%(v / v)$ A. ferrooxidans. The effective volume of the prepared $9 \mathrm{~K}-\mathrm{FeSO}_{4}-A$. ferrooxidans system was $250 \mathrm{~mL}$, where the A. ferrooxidans density was approximately $5 \times 10^{7}$ cells $/ \mathrm{mL}$. Then, based on the $\mathrm{Fe}^{2+}$ concentration of $9.67 \mathrm{~g} / \mathrm{L}, \mathrm{FeSO}_{4} \cdot 7 \mathrm{H}_{2} \mathrm{O}$ was accurately added and shaken for complete dissolution. The $\mathrm{pH}$ values of the solutions were adjusted to 2.50 by adding $1: 1(v / v) \mathrm{H}_{2} \mathrm{SO}_{4}$. The Erlenmeyer flasks were sealed with eight layers of gauze and placed in the shaker at 0,60,120, 180 and $240 \mathrm{rpm}$ at a constant temperature of $28{ }^{\circ} \mathrm{C}$ for a $120-\mathrm{h}$ biomineralization reaction. During the reaction period, the $\mathrm{Fe}^{2+}$ concentration, TFe precipitation efficiency and DO concentration were measured and calculated via regular sampling (after waiting for mineral precipitation, extract $1 \mathrm{~mL}$ of the supernatant passed through a $0.22-\mu \mathrm{m}$ filter membrane). At the end of the culture, the iron hydroxysulfate minerals were collected using 1004-055 Whatman filter paper (Grade 4: 20-25 $\mu \mathrm{m}$ ), which was rinsed twice with deionized water to eliminate the ions adsorbed on the minerals and the minerals were weighed after drying at $60{ }^{\circ} \mathrm{C}$ for $24 \mathrm{~h}$, with each treatment conducted in triplicate. 


\subsection{Effect of the $\mathrm{O}_{2}$ Supply Time on the A. ferrooxidans-Mediated Biomineralization}

The DO concentration in the solution returned to the initial level and remained stable after $9.67 \mathrm{~g} / \mathrm{L}$ of $\mathrm{Fe}^{2+}$ in the system was completely oxidized by A. ferrooxidans at shaking speeds of 120 and $180 \mathrm{rpm}(40 \mathrm{~h})$. However, the TFe precipitation efficiency continuously increased between 40 and $120 \mathrm{~h}$. This response provides motivation to investigate the role of DO in the A. ferrooxidans-mediated biomineralization.

Another series of $500-\mathrm{mL}$ Erlenmeyer flasks with $250 \mathrm{~mL}$ of the $9 \mathrm{~K}-\mathrm{FeSO}_{4}-A$. ferrooxidans solution ( $\mathrm{pH}$ of $2.50, \mathrm{Fe}^{2+}$ concentration of $9.67 \mathrm{~g} / \mathrm{L}$ and $A$. ferrooxidans density of approximately $5 \times 10^{7}$ cells $/ \mathrm{mL}$ ) was prepared. The prepared system was divided according to the $\mathrm{O}_{2}$ supply times as follows. In treatment (1) ("unlimited $\mathrm{O}_{2}$ supply"), the Erlenmeyer flasks were sealed with eight layers of gauze and placed in a shaker at $28^{\circ} \mathrm{C}$ and $180 \mathrm{rpm}$ for biologic oxidation and hydrolytic mineralization. During the culture, the DO concentration, $\mathrm{Fe}^{2+}$ oxidation and TFe precipitation efficiency were measured and calculated at 0 and every $12 \mathrm{~h}$ up to $120 \mathrm{~h}$ (after waiting for mineral precipitation, extract $1 \mathrm{~mL}$ of the supernatant passed through a $0.22-\mu \mathrm{m}$ filter membrane). In treatment (2) ("limited $\mathrm{O}_{2}$ supply at $0 \mathrm{~h}$ "), the eight layers of gauze in treatment (1) were replaced with rubber plugs equipped with samplers, suction ducts and DO monitors (Figure 1). The suction ducts were connected to vacuum pumps, and pumping was initiated, creating a relative pressure of $-0.098-\mathrm{MPa}$ in Erlenmeyer flasks. Subsequently, the catheter valves were closed. Then, the Erlenmeyer flasks were placed in a shaker at $28{ }^{\circ} \mathrm{C}$ and $180 \mathrm{rpm}$ for the biomineralization reaction. Sampling was performed and parameters were calculated according to treatment (1). Treatment (3) ("limited $\mathrm{O}_{2}$ supply at 36 h") involved biomineralization reactions according to treatment (1) for assessing the oxidation efficiency of the $\mathrm{Fe}^{2+}$ in the $9 \mathrm{~K}-\mathrm{FeSO}_{4}$-A. ferrooxidans system. After the $\mathrm{Fe}^{2+}$ oxidation efficiency reached $100 \%$ (monitoring determined that the time was $36 \mathrm{~h}$ ), the eight layers of gauze were replaced by rubber plugs as in treatment (2), and the vacuum pumps were initiated to ensure that the relative pressure in the flask was $-0.098 \mathrm{MPa}$. Further, the catheter valves were closed. The Erlenmeyer flasks were placed in the shaker at $28^{\circ} \mathrm{C}$ and $180 \mathrm{rpm}$ for the reaction to proceed, and sampling was performed for determining and calculating various parameters; each treatment was performed in triplicate.

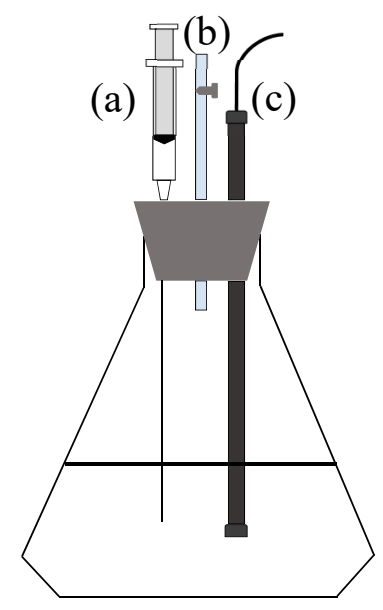

Figure 1. Erlenmeyer flask with a (a) sampler, (b) suction tube and (c) dissolved $\mathrm{O}_{2}$ (DO) monitor installed on the rubber stopper.

After $120 \mathrm{~h}$ of the biomineralization reaction, the iron hydroxysulfate minerals were collected using Whatman No. 4 filter paper, washed twice with deionized water to eliminate the adsorbed ions, and weighed after drying at $60{ }^{\circ} \mathrm{C}$ for $24 \mathrm{~h}$. The minerals obtained from the three treatments were identified via X-ray diffraction (XRD) analyses, and their characteristics were observed via scanning electron microscopy (SEM). 


\subsection{Determination Methods}

The $\mathrm{pH}$ values of the solutions were determined using a $\mathrm{pH}$ S-3C precision $\mathrm{pH}$ meter, whereas the DO concentrations were measured using a portable dissolved oxygen analyzer (JPB-607A). The Fe ${ }^{2+}$ and TFe concentrations were determined via the 1,10-phenanthroline method using a spectrophotometer [35]. Then, the $\mathrm{Fe}^{2+}$ oxidation efficiency and the TFe precipitation efficiency were calculated according to the following formulas.

$\mathrm{Fe}^{2+}$ oxidation efficiency $(\%)=\left[\left(\mathrm{C}_{\mathrm{Fe}(\mathrm{II})}-\mathrm{C}_{\mathrm{Fe}(\mathrm{II})}\right) / \mathrm{C}_{\mathrm{Fe}(\mathrm{II})}\right] \times 100 \%$, where $\mathrm{C}_{\mathrm{Fe}(\mathrm{II})}$ is the initial $\mathrm{Fe}^{2+}$ concentration $(\mathrm{mg} / \mathrm{L})$ and $\mathrm{C}^{\prime}{ }_{\mathrm{Fe}}(\mathrm{II})$ is the $\mathrm{Fe}^{2+}$ concentration $(\mathrm{mg} / \mathrm{L})$ at different times.

TFe precipitation efficiency $(\%)=\left[\left(\mathrm{C}_{\mathrm{TFe}}-\mathrm{C}_{\mathrm{TFe}}\right) / \mathrm{C}_{\mathrm{TFe}}\right] \times 100 \%$, where $\mathrm{C}_{\mathrm{TFe}}$ is the initial TFe concentration $(\mathrm{mg} / \mathrm{L})$ and $\mathrm{C}^{\prime} \mathrm{TFe}$ is the TFe concentration $(\mathrm{mg} / \mathrm{L})$ at different times.

The density of $A$. ferrooxidans was measured using the double-layer plate method [36]. Briefly, $0.1 \mathrm{~mL}$ of the heterotrophic yeast strain Rhodotorula sp. R30 solution was spread onto the bottom layer made of $2 \%$ agar in plate. Then, the mineral-salt medium containing $0.4 \%$ agarose with respect to $A$. ferrooxidans were poured on it as the upper layer; after the plates were cold, $0.1 \mathrm{~mL}$ of the bacterial suspension containing $A$. ferrooxidans was evenly spread on the superstratum and cultured for $15 \mathrm{~d}$ at $30{ }^{\circ} \mathrm{C}$. Further, the bacterial colony on the plate was assessed. The precipitated mineral phases were analyzed via XRD (Bruker D8A25, Bruker Corporation, Karlsruhe, Germany) using $\mathrm{CuK} \alpha$ radiation $(40 \mathrm{kV}, 40 \mathrm{~mA})$; the samples were scanned from $2 \theta=10^{\circ}$ to $80^{\circ}$ with an increment step of $0.01^{\circ}$ and a scanning speed of $6^{\circ} / \mathrm{min}$. The morphology of the precipitates was examined via field-emission scanning electron microscopy (FE-SEM, SU8010) [37], whereas the specific surface areas of the secondary iron minerals were determined using the Brunauer-Emmett-Teller (BET) adsorption method (Micromeritic ASAP 2020) [38].

\section{Results and Discussion}

\subsection{Effect of Hydraulic Shear Force on the $\mathrm{Fe}^{2+}$ Oxidation and TFe Precipitation Efficiency}

Generally, the faster the rotating speed of the shaker, the more will be the consumption of $\mathrm{Fe}^{2+}$ by A. ferrooxidans (Figure 2). During biologic oxidation, $A$. ferrooxidans oxidizes the $\mathrm{Fe}^{2+}$ in the system to $\mathrm{Fe}^{3+}$. Further, $\mathrm{Fe}^{3+}$ precipitates through hydrolysis with other metal ions or $\mathrm{SO}_{4}{ }^{2-}$ in the solution as iron hydroxysulfate minerals, eliminating soluble Fe [25,39]. Bai et al. [40] indicated that the $\mathrm{Fe}^{3+}$ supply rate was an important factor affecting mineral formation in the biomineralization system containing $A$. ferrooxidans, with a higher rate promoting mineral formation. Increasing the hydraulic shear force accelerates the supply rate of the oxidation product $\mathrm{Fe}^{3+}$ during biomineralization, with $\mathrm{TFe}$ precipitation efficiencies of $5.28 \%, 26.33 \%$ and $39.65 \%$ at 0,60 and $120 \mathrm{rpm}$ in the system at the end of the biomineralization reaction, respectively.

However, under approximately identical $\mathrm{Fe}^{3+}$ supply rates, very high shaker speeds (240 rpm) adversely affected the removal of TFe from the $9 \mathrm{~K}-\mathrm{FeSO}_{4}-$ A ferrooxidans system. Thomas [41] and Doran [42] indicated that bacterial mineralization is weakened because of their inability to adhere to the solid surface in a strong stirring environment, significantly reducing the TFe removal efficiency of the solution. The changes in TFe precipitation efficiency directly reflect the formation potential of the iron hydroxysulfate minerals in the system [40]. Based on Figure 3, at the end of biomineralization, the TFe precipitation efficiencies of the system at $0,60,120,180$ and $240 \mathrm{rpm}$ were 5.28\%, 26.33\%, $39.65 \%, 41.28 \%$ and $33.38 \%$, respectively, with corresponding iron hydroxysulfate mineral masses of $0.24,0.87,1.25,1.47$ and $1.02 \mathrm{~g}$.

A. ferrooxidans is an exclusive aerobic microbe. With $\mathrm{O}_{2}$ as the only electron acceptor for $\mathrm{Fe}^{2+}$ oxidation, $A$. ferrooxidans utilizes the energy released by this oxidation for its growth and reproduction. Therefore, sufficient supply of $\mathrm{O}_{2}$ is a necessary condition for the growth of $A$. ferrooxidans [27,28]. The DO variations in the $9 \mathrm{~K}-\mathrm{FeSO}_{4}-A$. ferrooxidans system under different hydraulic shear forces are displayed in Figure 4. 


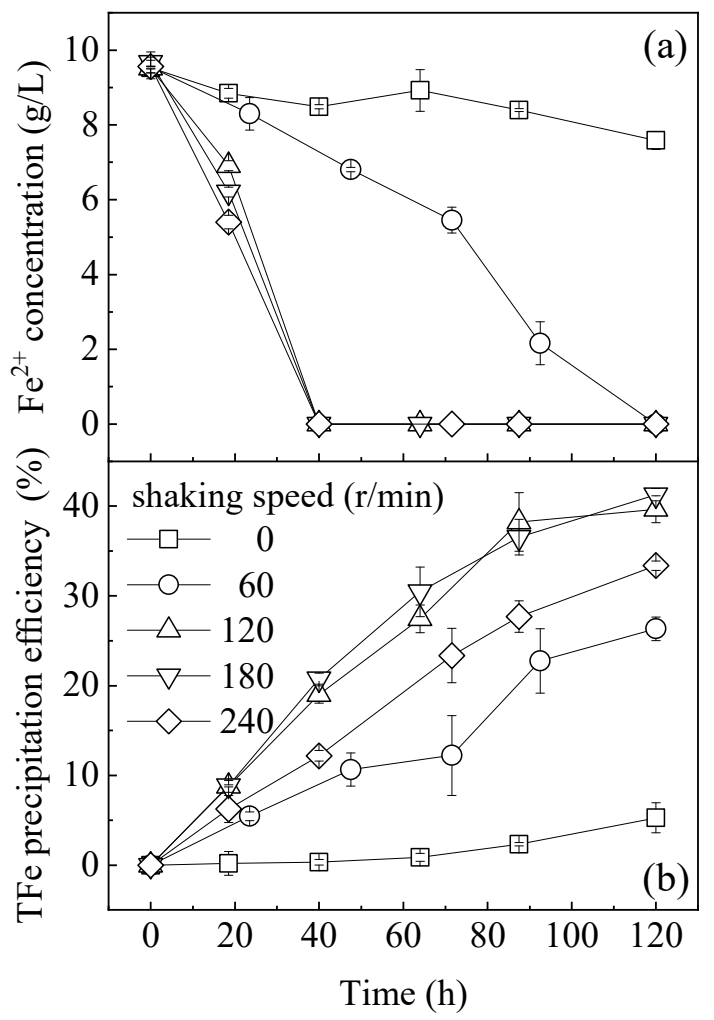

Figure 2. Effect of hydraulic shear force on the (a) $\mathrm{Fe}^{2+}$ concentration and (b) TFe precipitation efficiency in the $9 \mathrm{~K}-\mathrm{FeSO}_{4}-A$. ferrooxidans system.

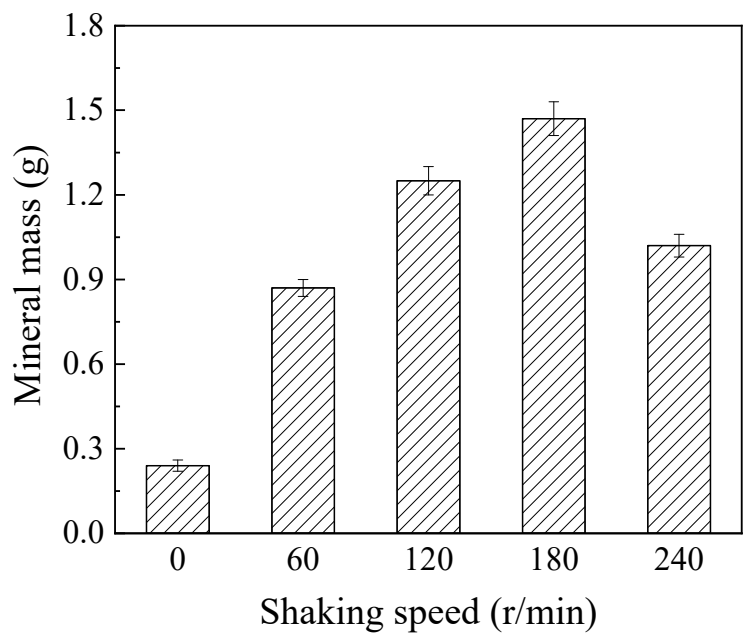

Figure 3. Comparison of the biosynthetic iron hydroxysulfate mineral mass with respect to different hydraulic shear forces.

When the reaction proceeds at 0 or $60 \mathrm{rpm}$, the DO concentration in the solution gradually decreases from approximately $9.50 \mathrm{mg} / \mathrm{L}$ at the beginning to 6.32 and $5.21 \mathrm{mg} / \mathrm{L}$ after $120 \mathrm{~h}$, respectively. As the speed of the shaker was increased to 120 and $180 \mathrm{rpm}$, the DO concentration in the system (approximately $9.50 \mathrm{mg} / \mathrm{L}$ ) initially decreased to 5.38 and $6.91 \mathrm{mg} / \mathrm{L}$, respectively, after $20 \mathrm{~h}$ and then becomes $9.26 \mathrm{mg} / \mathrm{L}$ and $9.64 \mathrm{mg} / \mathrm{L}$, respectively, after $40 \mathrm{~h}$. If the nutrient supply is sufficient, the amount of $A$. ferrooxidans in the system can increase by a hundred times as the culture time increases when compared with that observed during the initial stage of the reaction [21]. In this case, the $\mathrm{O}_{2}$ needed for the biologic oxidation of $\mathrm{Fe}^{2+}$ in the solution gradually increases, and the dissolution rate of the air $\mathrm{O}_{2}$ is insufficient to support the $\mathrm{O}_{2}$ consumption of A. ferrooxidans during the $\mathrm{Fe}^{2+}$ oxidation 
process, gradually decreasing the solution's DO concentration. However, the concentration of $\mathrm{Fe}^{2+}$ will decrease gradually when the density of $A$. ferrooxidans is high. At this time, the $\mathrm{Fe}^{2+}$ concentration becomes the main limiting factor with respect to the biologic oxidation reaction [43]. Further, biologic oxidation wanes and the $\mathrm{O}_{2}$ needed for oxidation reduces. Because of the $\mathrm{O}_{2}$ obtained from the air, the $\mathrm{DO}$ concentration in the solution slowly increases, attaining a stable state.

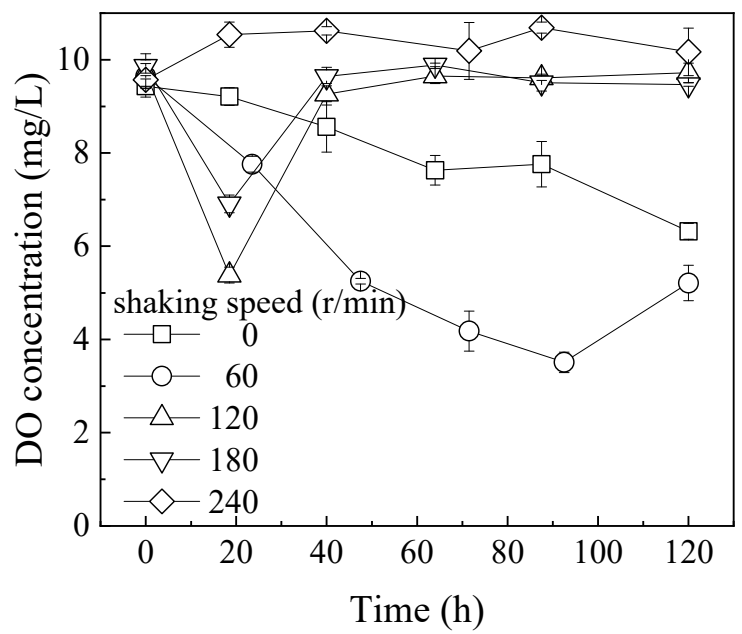

Figure 4. Effect of the hydraulic shear force on the DO concentration of the $9 \mathrm{~K}-\mathrm{FeSO}_{4}$ A. ferrooxidans system.

Figure 2 shows that the TFe precipitation efficiency of the solution increases as the mineralization reaction time increases after the complete biologic oxidation of $\mathrm{Fe}^{2+}$ in the $9 \mathrm{~K}-\mathrm{FeSO}_{4}-A$. ferrooxidans system. Compared with Figure 4, for a biomineralization lasting for $40 \mathrm{~h}$, the DO concentration in the system at 120 and $180 \mathrm{rpm}$ returns to the initial level, indicating that DO was not involved in the hydrolytic mineralization of $\mathrm{Fe}^{3+}$. Liao et al. [26] noted that after inoculating A. ferrooxidans into an $\mathrm{Fe}_{2}\left(\mathrm{SO}_{4}\right)_{3}$ solution and waiting for $40 \mathrm{~h}$ (equivalent to a rotation speed of $0 \mathrm{rpm}$ ), the Fe concentration in the solution gradually decreases, producing a small amount of minerals. However, the study lacked an in-depth discussion about the causes of this phenomenon.

\subsection{Effect of the $\mathrm{O}_{2}$ Supply Time on the Formation of Iron Hydroxysulfate Minerals}

Three groups of control experiments were conducted to further determine the function of $\mathrm{O}_{2}$ in $\mathrm{Fe}$ precipitate formation (Section 2.4). As shown in Figure 5, in the treatment "limited $\mathrm{O}_{2}$ supply at $0 \mathrm{~h}$," the $\mathrm{O}_{2}$ in air cannot dissolve in the $9 \mathrm{~K}-\mathrm{FeSO}_{4}-A$. ferrooxidans system, whereas the $\mathrm{O}_{2}$ in the solution diffuses into the air owing to the difference in concentration. Accordingly, a marked inhibition of $\mathrm{Fe}^{2+}$ bio-oxidation and TFe precipitation efficiency could be observed, as indicated by the low $\mathrm{Fe}^{2+}$ oxidation efficiency $(16.26 \%)$ and TFe precipitation efficiency $(4.25 \%)$ at the end of the reaction $(120 \mathrm{~h})$. This suggests that relying only on the DO remaining in the initial reaction solution barely supports the $\mathrm{O}_{2}$ requirement for the formation of iron hydroxysulfate minerals when A. ferrooxidans should utilize $\mathrm{O}_{2}$ to oxidize $\mathrm{Fe}^{2+}$ and obtain energy for its growth $[27,28]$.

The DO concentration in the "unlimited $\mathrm{O}_{2}$ supply" treatment decreases to its lowest value $(3.17 \mathrm{mg} / \mathrm{L})$ at $36 \mathrm{~h}$ and then rapidly increases to the initial level $(9.52 \mathrm{mg} / \mathrm{L})$ and remains stable at $48 \mathrm{~h}$. Furthermore, almost similar dynamic changes were observed with respect to the $\mathrm{Fe}^{2+}$ oxidation efficiency and TFe precipitation efficiency in the "unlimited $\mathrm{O}_{2}$ supply" and "limited $\mathrm{O}_{2}$ supply at $36 \mathrm{~h}^{\prime \prime}$ treatments. This suggests that the supply of $\mathrm{O}_{2}$ had an important function in the oxidation of $\mathrm{Fe}^{2+}$ to $\mathrm{Fe}^{3+}$ by A. ferrooxidans; however, its function in the formation of iron hydroxysulfate minerals could be neglected possibly because the energy released from the oxidation of $\mathrm{Fe}^{2+}$ can be used for the subsequent hydrolysis reaction of $\mathrm{Fe}^{3+}$ into minerals [44,45]. This was advantageous to significantly 
reduce the AMD biomineralization treatment cost because the $\mathrm{O}_{2}$ charging operation of aeration can be stopped after complete $\mathrm{Fe}^{2+}$ oxidization by A. ferrooxidans.

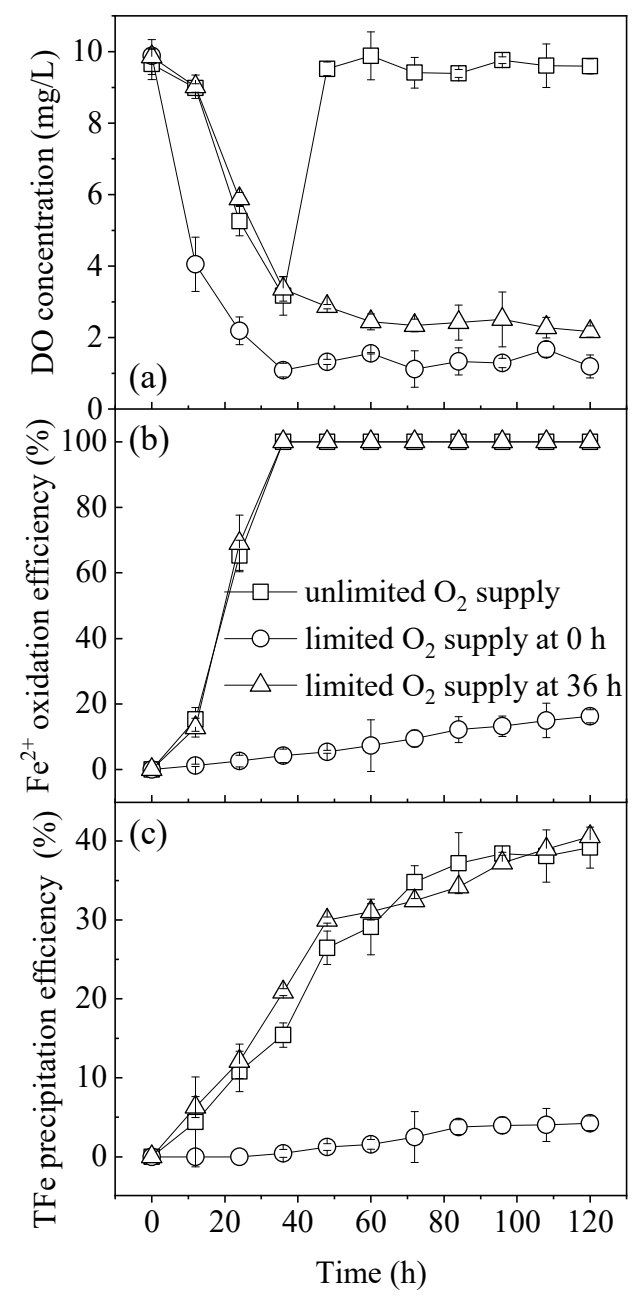

Figure 5. Effects of $\mathrm{O}_{2}$ supply time on the (a) DO concentration, (b) $\mathrm{Fe}^{2+}$ oxidation and (c) TFe precipitation efficiency during $A$. ferrooxidans-mediated biomineralization.

\subsection{Characteristics of the Minerals Obtained from Different $\mathrm{O}_{2}$ Supply Conditions}

Generally, XRD is employed to analyze the mineral phases [46,47]. The XRD patterns of three biogenic iron hydroxysulfate minerals obtained using different $\mathrm{O}_{2}$ supply times are presented in Figure 6. Based on standards [48], the product obtained from the "limited $\mathrm{O}_{2}$ supply at $0 \mathrm{~h}$ " treatment after biomineralization for $120 \mathrm{~h}$ was schwertmannite, whereas the remaining two treatment systems produce a mixture of schwertmannite and jarosite. Based on Figure 5, the oxidation efficiency of $\mathrm{Fe}^{2+}$ can be determined using the $\mathrm{O}_{2}$ supply time. At a low $\mathrm{Fe}^{2+}$ oxidation efficiency, the hydrolytic mineralization product of $\mathrm{Fe}^{3+}$ was mainly schwertmannite and a high $\mathrm{Fe}^{2+}$ oxidation efficiency promotes the formation of jarosite. Bai et al. [49] observed that either amorphous schwertmannite or crystalline jarosite existed at the critical point of jarosite formation in a $\mathrm{FeSO}_{4}-\mathrm{K}_{2} \mathrm{SO}_{4}-\mathrm{H}_{2} \mathrm{O}$ system with $A$. ferrooxidans and depended on the rate of $\mathrm{Fe}^{3+}$ supply. The low supply rate of $\mathrm{Fe}^{3+}$ obviously inhibited the incorporation of $\mathrm{K}^{+}$into the iron hydroxysulfate mineral to form jarosite, improving the generation of amorphous schwertmannite in the system.

Figure 7 shows the SEM images of the iron hydroxysulfate minerals mediated by A. ferrooxidans under different $\mathrm{O}_{2}$ supply times. Schwertmannite agglomeration was obvious during the "limited $\mathrm{O}_{2}$ supply at $0 \mathrm{~h}$ " treatment. The mineral particles exhibit "chestnut shell" and "sea urchin" shapes, with their surfaces covered with needle-like burrs. Further, their average specific surface areas 
$\left(42.12 \mathrm{~m}^{2} / \mathrm{g}\right)$ were considerably higher than the range $\left(4-14 \mathrm{~m}^{2} / \mathrm{g}\right)$ reported for schwertmannite by Regenspurg et al. [15]. Similar to the results of this study, Loan et al. [16,23,50] observed that the schwertmannite formed in an acidic mine environment dominantly displayed a spherical "sea urchin"-like structure, which had a diameter of only 300-500 nm and the surface of which was covered with 60-90-nm needle-like burrs. When compared with the structure of the minerals obtained via the "limited $\mathrm{O}_{2}$ supply at $0 \mathrm{~h}$ " treatment, the apparent structure of the minerals obtained from the "unlimited $\mathrm{O}_{2}$ supply" and "limited $\mathrm{O}_{2}$ supply at $36 \mathrm{~h}$ " treatments clearly differ. The crystallinity of schwertmannite was poor with a distributed network, whereas the jarosite minerals display obvious crystallinity and were relatively dispersed on the schwertmannite surfaces. This is consistent with Sasaki and Konno's results that biosynthetic jarosite comprises many micron-sized crystals with clear edges and corners and smooth surfaces [51]. The average specific surface areas of the mixtures obtained via the two treatments were 28.97 and $31.53 \mathrm{~m}^{2} / \mathrm{g}$, respectively.

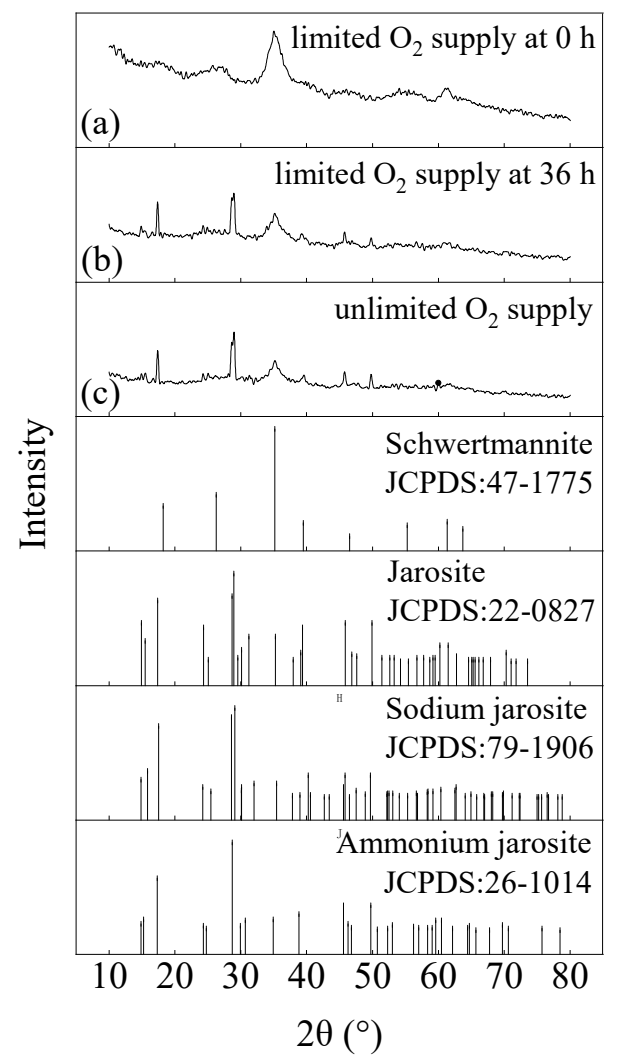

Figure 6. XRD patterns of the iron hydroxysulfate minerals mediated by A. ferrooxidans under different $\mathrm{O}_{2}$ supply times, i.e., (a) limited $\mathrm{O}_{2}$ supply at $0 \mathrm{~h}$; (b) limited $\mathrm{O}_{2}$ supply at $36 \mathrm{~h}$ and (c) unlimited $\mathrm{O}_{2}$ supply.

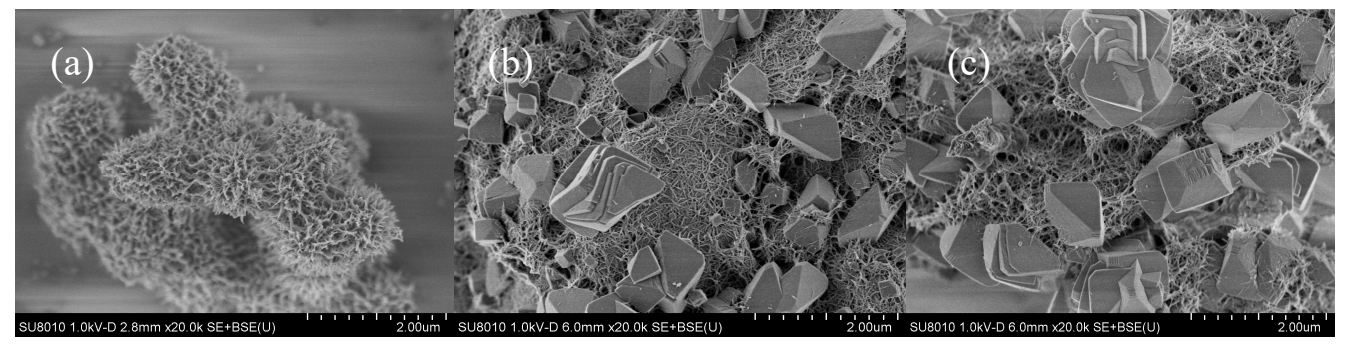

Figure 7. Scanning electron microscopy (SEM) images of the iron hydroxysulfate minerals mediated by A. ferrooxidans under different $\mathrm{O}_{2}$ supply times, i.e., (a) limited $\mathrm{O}_{2}$ supply at 0 h; (b) limited $\mathrm{O}_{2}$ supply at $36 \mathrm{~h}$ and (c) unlimited $\mathrm{O}_{2}$ supply. 


\section{Conclusions}

In this study, we demonstrated that in a $9 \mathrm{~K}_{-} \mathrm{FeSO}_{4}-A$. ferrooxidans system, the greater the hydraulic shear force (the higher the shaker speed), the higher will be the utilization of $\mathrm{Fe}^{2+}$ by A. ferrooxidans. Regardless, a very high shaker speed (e.g., $240 \mathrm{rpm}$ ) adversely impacted the hydrolytic mineralization and precipitation of $\mathrm{Fe}^{3+}$ in the system. Based on the $\mathrm{Fe}^{2+}$ biologic oxidation efficiency and TFe precipitation capacity, shaking table speeds of 120-180 rpm were optimum for efficiently synthesizing iron hydroxysulfate minerals. In addition, the effect of $\mathrm{O}_{2}$ supply time on the A. ferrooxidans biomineralization process confirmed that the DO in the system was mainly consumed by the biologic oxidation of $\mathrm{Fe}^{2+}$. After $\mathrm{Fe}^{2+}$ was completely oxidized by A. ferrooxidans, the hydrolytic precipitation efficiency of the oxidation product $\mathrm{Fe}^{3+}$ was independent of the $\mathrm{O}_{2}$ supply. The XRD and SEM analyses demonstrated that when $\mathrm{Fe}^{2+}$ is completely oxidized in the $9 \mathrm{~K}^{2}-\mathrm{FeSO}_{4}$-A. ferrooxidans system, the $\mathrm{O}_{2}$ supply did not alter the mineral precipitated via $\mathrm{Fe}^{3+}$ hydrolysis, mainly comprising partially amorphous schwertmannite and jarosite with good crystallinity.

Author Contributions: J.Y. conceived and designed this study. R.W. performed the experiments and conducted data collation and analysis. H.W. contributed to the revision of the manuscript. Y.S. collated the data, performed analysis and wrote the manuscript. All authors have read and agreed to the published version of the manuscript.

Funding: This research was funded by the National Natural Science Foundation of China (21906183) and the Soft Science Foundation of Hubei Province, China [2019ADC152] and the Fundamental Research Funds for the Central Universities [2722020JCG068; 2722020PY061].

Acknowledgments: The authors would like to thank the Solid Waste Research Institute of Nanjing Agricultural University for providing A. ferrooxidans LX5 (CGMCC No. 0727). The authors would also like to thank Zhenyu Wang for kindly editing the manuscript.

Conflicts of Interest: The authors declare no conflict of interest.

\section{References}

1. Balci, N.; Demirel, C. Prediction of Acid Mine Drainage (AMD) and Metal Release Sources at the Küre Copper Mine Site, Kastamonu, NW Turkey. Mine Water Environ. 2018, 37, 56-74. [CrossRef]

2. Yucel, D.S.; Balci, N.; Baba, A. Generation of Acid Mine Lakes Associated with Abandoned Coal Mines in Northwest Turkey. Arch. Environ. Contam. Toxicol. 2016, 70, 757-782. [CrossRef]

3. Balci, N.; Shanks, W.C., III; Mayer, B.; Mandernack, K.W. Oxygen and sulfur isotope systematics of sulfate produced by bacterial and abiotic oxidation of pyrite. Geochim. Cosmochim. Acta 2007, 71, 3796-3811. [CrossRef]

4. Cravotta, C.A.; Trahan, M.K. Limestone drains to increase $\mathrm{pH}$ and remove dissolved metals from acidic mine drainage. Appl. Geochem. 1999, 14, 581-606. [CrossRef]

5. Vhahangwele, M. A novel technology for neutralizing acidity and attenuating toxic chemical species from acid mine drainage using cryptocrystalline magnesite tailings. J. Water Process Eng. 2016, 10, 67-77.

6. Wang, X.M.; Jiang, H.K.; Fang, D.; Liang, J.R.; Zhou, L.X. A novel approach to rapidly purify acid mine drainage through chemically forming schwertmannite followed by lime neutralization. Water Res. 2019, 151, 515-522. [CrossRef]

7. Song, Y.W.; Wang, M.; Liang, J.R.; Zhou, L.X. High-rate precipitation of iron as jarosite by using a combination process of electrolytic reduction and biological oxidation. Hydrometallurgy 2014, 143, 23-27. [CrossRef]

8. Meschke, K.; Herdegen, V.; Aubel, T.; Janneck, E.; Repke, J.U. Treatment of opencast lignite mining induced acid mine drainage (AMD) using a rotating microfiltration system. J. Environ. Chem. Eng. 2015, 4, 2848-2856. [CrossRef]

9. Lee, W.C.; Lee, S.W.; Yun, S.T.; Lee, P.K.; Hwang, Y.S.; Kim, S.O. A novel method of utilizing permeable reactive kiddle (PRK) for the remediation of acid mine drainage. J. Hazard. Mater. 2016, 301, 332-341. [CrossRef]

10. Umita, T. Biological mine drainage treatment. Resour. Conserv. Recycl. 1996, 16, 179-188. [CrossRef]

11. Bosecker, K. Bioleaching: Metal solubilization by microorganisms. FEMS Microbiol. Rev. 1997, 20, 591-604. [CrossRef] 
12. Valente, T.; Grande, J.A.; De, I.T.M.L.; Santisteban, M.; Cerón, J.C. Mineralogy and environmental relevance of AMD-precipitates from the Tharsis mines, Iberian Pyrite Belt (SW, Spain). Appl. Geochem. 2013, 39, 11-25. [CrossRef]

13. Zhu, J.Y.; Gan, M.; Zhang, D.; Hu, Y.H.; Chai, L.Y. The nature of schwertmannite and jarosite mediated by two strains of Acidithiobacillus ferrooxidans with different ferrous oxidation ability. Mater. Sci. Eng. C 2013, 33, 2679-2685. [CrossRef] [PubMed]

14. Diao, Z.H.; Shi, T.H.; Wang, S.Z.; Huang, X.F.; Zhang, T.; Tang, Y.T.; Zhang, X.Y.; Qiu, R.L. Silane-based coatings on the pyrite for remediation of acid mine drainage. Water Res. 2013, 47, 4391-4402. [CrossRef]

15. Regenspurg, S.; Brand, A.; Peiffer, S. Formation and stability of schwertmannite in acid mining lakes. Geochim. Cosmochim. Acta 2004, 68, 1185-1197. [CrossRef]

16. Loan, M.; Richmond, W.R.; Parkinson, G.M. On the crystal growth of nanoscale schwertmannite. J. Cryst. Growth 2005, 275, 1875-1881. [CrossRef]

17. Barham, R.J. Schwertmannite: A unique mineral, contains a replaceable ligand, transforms to jarosites, hematites, and/or basic iron sulfate. J. Mater. Res. 1997, 12, 2751-2758. [CrossRef]

18. Min, G.; Sun, S.J.; Zheng, Z.H.; Tang, H.J.; Sheng, J.R.; Zhu, J.Y.; Liu, X.X. Adsorption of Cr(VI) and Cu(II) by $\mathrm{AlPO}_{4}$ modified biosynthetic schwertmannite. Appl. Surf. Sci. 2015, 356, 986-997.

19. Zhang, S.L.; Jia, S.Y.; Yu, B.; Liu, Y.; Wu, S.H.; Han, X. Sulfidization of As(V)-containing schwertmannite and its impact on arsenic mobilization. Chem. Geol. 2016, 420, 270-279. [CrossRef]

20. Song, Y.W.; Zhang, J.Y.; Wang, H.R. Initial $\mathrm{pH}$ and $\mathrm{K}^{+}$concentrations jointly determine the types of biogenic ferric hydroxysulfate minerals and their effect on adsorption removal of $\mathrm{Cr}(\mathrm{VI})$ in simulated acid mine drainage. Water Sci. Technol. 2018, 78, 2183-2192. [CrossRef]

21. Dutrizac, J.E.; Kaiman, S. Synthesis and properties of jarosite-type compounds. Can. Mineral. 1976, 14, 151-158.

22. Dutrizac, J.E. The effectiveness of jarosite species for precipitating sodium jarosite. J. Mineral. Met. Mater. Soc. 1999, 51, 30-32. [CrossRef]

23. Gramp, J.P.; Jones, F.S.; Bigham, J.M.; Tuovinen, O.H. Monovalent cation concentrations determine the types of Fe(III) hydroxysulfate precipitates formed in bioleach solutions. Hydrometallurgy 2008, 94, 29-33. [CrossRef]

24. Song, Y.W.; Wang, H.R.; Yang, J.; Cao, Y.X. Influence of monovalent cations on the efficiency of ferrous ion oxidation, total iron precipitation, and adsorptive removal of $\mathrm{Cr}(\mathrm{VI})$ and $\mathrm{As}(\mathrm{III})$ in simulated acid mine drainage with inoculation of Acidithiobacillus ferrooxidans. Metals 2018, 8, 596. [CrossRef]

25. Bigham, J.M.; Schwertmann, U.; Pfab, G. Influence of $\mathrm{pH}$ on mineral speciation in a bioreactor simulating acid mine drainage. Appl. Geochem. 1996, 11, 845-849. [CrossRef]

26. Liao, Y.H.; Zhou, L.X.; Liang, J.R.; Xiong, H.X. Biosynthesis of schwertmannite by Acidithiobacillus ferrooxidans cell suspensions under different $\mathrm{pH}$ condition. Mater. Sci. Eng. C 2009, 29, 211-215. [CrossRef]

27. Jensen, A.B.; Webb, C. Ferrous sulphate oxidation using Thiobacillus ferrooxidans: A review. Process Biochem. 1995, 30, 225-236. [CrossRef]

28. Daoud, J.; Karamanev, D. Formation of jarosite during $\mathrm{Fe}^{2+}$ oxidation by Acidithiobacillus ferrooxidans. Mineral. Eng. 2006, 19, 960-967. [CrossRef]

29. Ohmura, N.; Sasaki, K.; Matsumoto, N.; Saiki, H. Anaerobic respiration using $\mathrm{Fe}^{3+}, \mathrm{S}^{0}$, and $\mathrm{H}_{2}$ in the chemolithoautotrophic bacterium Acidithiobacillus ferrooxidans. J. Bacteriol. 2002, 184, 2081-2087. [CrossRef]

30. Goodman, A.E.; Babij, T.; Ritchie, A.I.M. Leaching of a sulphide ore by Thiobacillus ferrooxidans under anaerobic conditions. In Biohydrometallurgy; Rossi, G., Torma, A.E., Eds.; Associazionen Mineraria Sarde, Iglesias: Iglesias, Italy, 1983; pp. 361-376.

31. Magdalena, G.; Roger, B.H.J.; Paul, C.F.K. Pyrite oxidation by Acidithiobacillus ferrooxidans at various concentrations of dissolved oxygen. Chem. Geol. 2006, 225, 16-19.

32. Wang, Z.; Che, J.; Ye, C. Application of ferric chloride both as oxidant and complexant to enhance the dissolution of metallic copper. Hydrometallurgy 2010, 105, 69-74. [CrossRef]

33. Sun, L.X.; Zhang, X.; Tan, W.S.; Zhu, M.L. Effect of agitation intensity on the biooxidation process of refractory gold ores by Acidithiobacillus ferrooxidans. Hydrometallurgy 2012, 127-128, 99-103. [CrossRef]

34. Silverman, M.P.; Lundgren, D.G. Studies on the chemoautotrophic iron bacterium Ferrobacillus ferrooxidans. I. An improved medium and a harvesting procedure for securing high cell yields. J. Bacteriol. 1959, 77, 642-647. [CrossRef] 
35. American Public Health Association. Standard Methods for the Examination of Water and Wastewater; American Water Works Assn: Washington, DC, USA, 2012.

36. Wang, S.M.; Zhou, L.X. A renovated approach for increasing colony count efficiency of Thiobacillus ferrooxidans and Thiobacillus thiooxidans: Double-layer plates. Acta Sci. Circumstantiae 2005, 25, 1418-1420.

37. Liu, F.W.; Gao, S.Y.; Wang, M.; Yu, H.Y.; Cui, C.H.; Zhou, L.X. Effect of KOH on the formation of biogenic secondary iron minerals in iron- and sulfate-rich acidic environment. Acta Sci. Circumstantiae 2015, 35, 476-483.

38. Manna, B.; Ghosh, U.C. Adsorption of arsenic from aqueous solution on synthetic hydrous stannic oxide. J. Hazard. Mater. 2007, 144, 522-531. [CrossRef] [PubMed]

39. Schwertmann, U.; Bigham, J.M.; Murad, E. The first occurrence of schwertmannite in a natural stream environment. Eur. J. Mineral. 1995, 7, 547-552. [CrossRef]

40. Bai, S.Y.; Liang, J.R.; Zhou, L.X. Effects of monovalent cation and dissolved organic matter on the formation of biogenic secondary iron minerals in bioleaching system. Acta Mineral. Sin. 2011, 31, 118-125.

41. Thomas, C.R. Problems of shear in biotechnology. In Chemical Engineering Problems in Biotechnology; Elsevier: Oxford, UK, 1990; pp. 23-93.

42. Doran, M.P. Bioprocess Engineering Principles; Academic Press: San Diego, CA, USA, 1995.

43. Liu, J.S.; Zhang, Y.H.; Li, B.M. The study kinetic for growth of Acidithiobacillus ferrooxidans. J. Microbiol. 2006, 2, 9-13.

44. Majzlan, J.; Navrotsky, A. Thermodynamics of iron oxides: Part III. Enthalpies of formation and stability of ferrihydrite $\left(-\mathrm{Fe}(\mathrm{OH})_{3}\right)$, schwertmannite $\left(-\mathrm{FeO}(\mathrm{OH})_{3 / 4}\left(\mathrm{SO}_{4}\right)_{1 / 8}\right)$, and $\varepsilon-\mathrm{Fe}_{2} \mathrm{O}_{3}$. Geochim. Cosmochim. Acta 2004, 68, 1049-1059. [CrossRef]

45. Amouric, A.; Brochier, A.C.; Johnson, D.B.; Bonnefoy, V.; Hallberg, K.B. Phylogenetic and genetic variation among Fe(II)-oxidizing acidithiobacilli supports the view that these comprise multiple species with different ferrous iron oxidation pathways. Microbiology 2011, 157, 111-122. [CrossRef] [PubMed]

46. Wang, H.M.; Bigham, J.M.; Tuovinen, O.H. Formation of schwertmannite and its transformation to jarosite in the presence of acidophilic iron-oxidizing microorganisms. Mater. Sci. Eng. C 2006, 26, 588-592. [CrossRef]

47. Eskandarpour, A.; Onyango, M.S.; Ochieng, A.; Asai, S. Removal of fluoride ions from aqueous solution at low pH using schwertmannite. J. Hazard. Mater. 2008, 152, 571-579. [CrossRef] [PubMed]

48. Joint Committee on Powder Diffraction Standards (JCPDS). Mineral Powder Diffraction Files; International Center for Diffraction Data: Newtown Square, PA, USA, 2002; pp. 856-975.

49. Bai, S.Y.; Xu, Z.H.; Wang, M.; Liao, Y.H.; Liang, J.R.; Zheng, C.C.; Zhou, L.X. Both initial concentrations of $\mathrm{Fe}(\mathrm{II})$ and monovalent cations jointly determine the formation of biogenic iron hydroxysulfate precipitates in acidic sulfate-rich environments. Mater. Sci. Eng. C 2012, 32, 2323-2329. [CrossRef]

50. Liu, F.W.; Bu, Y.S.; Tian, G.J.; Cui, C.H.; Zhou, L.X. Influence of temperature and pH on dissolution behavior of biogenic Schwertmannite in acidic environment and the adsorption of $\mathrm{Cu}^{2+}$. Acta Sci. Circumstantiae 2013, 33, 2445-2451.

51. Sasaki, K.; Konno, H. Morphology of jarosite-group compounds precipitated from biologically and chemically oxidized Fe ions. Can. Mineral. 2000, 38, 45-56. [CrossRef]

(C) 2020 by the authors. Licensee MDPI, Basel, Switzerland. This article is an open access article distributed under the terms and conditions of the Creative Commons Attribution (CC BY) license (http://creativecommons.org/licenses/by/4.0/). 